\title{
A THEORETICAL PERSPECTIVE ON THE THERAPEUTIC ROLE OF CHILDREN'S FOLK SONGS
}

\author{
Authors: \\ Loredana Muntean $(\mathrm{PhD})$ \\ University of Oradea (Romania) \\ E-mail address of author: \\ lmuntean@uoradea.ro
}

\section{Lectors:}

\author{
Ferenc Mező (PhD) \\ Eszterhazy Károly University \\ Katalin Mező (PhD) \\ University of Debrecen
}

Muntean, L. (2020). A Theoretical Perspective on the Therapeutic Role of Children's Folk Songs. Különleges Bánásmód, 6. (1). 75-81. DOI 10.18458/KB.2020.1.75

\begin{abstract}
Absrtact
Starting from the idea that treating a problem is done more efficiently when we address the causes that generated it than when dealing with symptoms, respectively from theories that claim that most of the mental disorders have their roots in the mother-child relationship developed in the early childhood, through the paper entitled $A$ Theoretical Perspective on the Therapeutic Role of Children's Folk. Songs we intend to argue the more use of songs from children's folklore in music therapy. Thus, in the first part of the paper we bring to the attention of the main theories that demonstrate the importance of the mother-child relationship from the early childhood in order to a healthy evolution of the child from the point of view of its psychic development, with special emphasis on their expression through vocal singing. In the second part of the study we we propose to approach the defense mechanisms from the perspective of the positive functions that it performs in the case of normal persons, as a defense mechanism and defense behavior. In the third part of the paper, we present an analysis of the repertoire of songs from the children's folklore from the perspective of the content of ideas, of the structure of the melodic line, of the specific rhythms, as a mirror of the relationships that children develop with themselves and with others, in particular with my mother. In the fourth part of the paper we argue the use of songs from children's folklore in music therapy in order to trigger certain memories from the first childhood, so that the traumas that have not been overcome are then treated properly. The paper concludes with some final considerations.
\end{abstract}

Keywords: music therapy, defensive mechanisms, children's folk songs

Diszcipline: pedagogy 


\section{Absztrakt \\ A GYERMEK NÉPDALOK TERÁPIÁS SZEREPÉNEK ELMÉLETI PERSPEKTÍVÁJA}

A gyermek népdalok terápiás szerepének elméleti perspektívája címú tanulmány kiindulópontjai: 1) egyetértünk azzal, hogy bármilyen probléma megoldásában hatékonyabb, ha annak az okát és nem csak a tüneteit kezeljük;. 2) egyetértünk azon kötődésről szóló elméletekkel, amelyek azt állítják, hogy a legtöbb mentális rendellenesség a kora gyermekkorban kialakult anya-gyermek kapcsolatban gyökerezik; 3) nem utolsó sorban, úgy véljük, hogy a gyermekkori népdalok hatékonyan alkalmazhatók bizonyos rendellenességek kezelésében. Így tanulmányunk első részében azon kötődési elméletekre fókuszálunk, amelyek bizonyítják az anya-gyermek kapcsolat fontosságát a gyermek egészséges fejlődése - a pszichés fejlődés szempontjából, különös hangsúlyt fektetve az éneklésen keresztüli kifejezésre. A tanulmány második részében azon védekező mechanizmusokat mutatjuk be (mint védekező mechanizmus és a védekező viselkedés) a pozitív hatás szempontjából, amelyek akár normál személyeknél is megjelennek. A tanulmány harmadik részében a gyermek népdalok repertoárjának rövid elemzését mutatjuk be a tartalom szempontjából, a dallamvonal felépítése szempontjából és a speciális ritmusokat tekintve mivel mindezek tükrözik a gyermekek kapcsolatát önmagukkal és másokkal, különösen az édesanyával. A tanulmány negyedik részében, a gyermek népdalok zeneterápiában való alkalmazása mellett érvelünk, mivel ezek kiválthatnak bizonyos emlékeket a kora gyermekkorból úgy, hogy a leküzdetlen traumákat ezután megfelelően kezelik. A tanulmány néhány végső megfontolással zárul.

Kulcsszavak: zeneterápia, védekező mechanizmusok, gyermek népdalok

Diszciplínák: pszichológia, pedagógia

\section{Introduction}

The sonorous reality of the contemporary world is characterized by a complexity that is difficult to express in words. By its sometimes surprising and unusual, at times template, impersonal character, by its sometimes ancestral, other times futuristic sonorities, the music influences us all.

Present at every moment of human life, music manages to comfort the soul, to balance the mind, to restore harmony where needed, thus becoming a universal panacea and, at the same time, a foundation of music therapy.

As with other types of therapies, in melotherapy we look at the possibilities of applying attachment theories in terms of ensuring the conditions necessary for the patient to explore their own relation- ships and attachment models, so that they can capitalize on them in their life experiences. From this perspective, as Bowlby argues (1988, p. 138), the therapist's activity is carried out on the following five coordinates:

- Providing a secure basis for exploring the painful or unhappy aspects of the past or present, which affect the balance of the patient's inner universe;

- Encourage and permanently assist the patient in the process of knowing and recognizing the way of relating with oneself and others;

- Building a relationship that allows the patient to identify and import perceptions, constructs, defining expectations to outline 
certain behavioral patterns generated in relation to the type of attachment;

- To guide the patient in the often difficult and painful process of (re)discovering the situations experienced in childhood and / or adolescence, especially in relation to the parents, which could cause current behaviors;

- Facilitate the process of understanding and accepting the fact that the image about oneself, the behavioral patterns derived from previous experiences, or verbally induced by one of the parents repeating certain messages may or may not be useful in the present and future life. The therapist facilitates the understanding of old stereotypes and the process of remodeling the behavior by finding alternatives based on new models of thinking and action.

In the present work, we intend to present a theoretical perspective on the importance of songs from children's folklore in melotherapy, in order to construct defense mechanisms and behaviors with adjusting function for the human psyche. The approach of attachment theories comes to complement this idea insofar as we consider relevant the emotional relationship, which is established between the mother and the newborn, through the mother's vocal singing and through the specific repertoire.

\section{Attachment theories}

One of the starting points of this paper is the theories that, in general terms speaking, claim that the form of attachment to the first person providing care for a newborn is defining for the subsequent evolution of the individual. The connection between the mother and the newborn child is, according to theorists, the premise for developing the capacity of intra and interpersonal knowledge, re- flected in the level of human relationships founded and maintained in adulthood.

As Winnicott $(1964$, p. 88) states, "if you set out to describe a baby, you will find you are describing a baby and someone. A baby cannot exist alone, but is essentially part of a relationship." The new born comes to the world with a series of needs such as being protected, cared for, loved, and the mother is the one who can provide him/ her with safety, care, and love. The attachment relationship that develops between the two implies a particular communication and behavior, based on experiences and emotions specific to the period in which they are.

Bowlby defined attachment as a "lasting psychological connectedness between human beings."(1969, p. 194)Thus, the type of attachment becomes defining for the direction in which the individual evolves in the light of his ability to interact with other people.

Regarding the conditions and the way of establishing harmonious relationships between individuals, Bowlby (1988, p. 130), argues that "each must be aware of the other's point-of-view, his goals, feelings, and intentions, and each must so adjust his own behavior that some alignment of goals is negotiated. This requires that each should have reasonably accurate models of self and other which are regularly up-dated by free communication between them."

\section{Regression - a defense mechanism and de- fense behavior}

According to Freudian theories, defense mechanisms are defined in relation to human psychopathological manifestations. Vaillant (1993) takes a different position, arguing that "the presence of defenses is not, in itself, a proof of the disease. No matter how disorganized, unreasonable or condemnable the defenses may seem in the eyes of an 
external observer, they are nothing more than an adaptive response." (Approx. quote) (Ionescu, Jacquet, \&Lhote, 2002, p. 29)

In the context of the present paper, we propose to approach the defense mechanisms from the perspective of the positive functions that it performs in the case of normal persons. Authors of numerous publications such as: Lampl - de Grot, 1957; Bibring et al., 1961; Valenstein, in PlumpianMindlin, 1967 and Wallerstein, 1967; Lazarus, 1983; Roth and Cohen, 1986 and Van Der Leeuw, 1971, agree that defense mechanisms are indispensable for the proper functioning of the human psyche, performing an adaptive function.

Laplanche and Pontalis (1973) defined defense mechanisms as "different types of operations through which defense may be given specific expressions. Which of these mechanisms predominate in a given case depends upon the type of illness under consideration, upon the developmental stage reached, upon the extent to which the defensive conflict has been worked out, and so on.

It is generally agreed that the ego puts the defense mechanisms to use, but the theoretical question of whether their mobilization always presupposes the existence of an organized ego capable of sustaining them is an open one." (Bond, 1992, p. 127)

For Widlöcher, "defense is the set of operations whose purpose is to reduce intrapsychic conflict, making one of its elements inaccessible to conscious experience." (Ionescu, Jacquet, \& Lhote, 2002, p. 32)

The defense mechanism, as defined by Braconnier in Doron \& Parot (2006, p. 78), "encompasses all the means by which the self relies to control, control and channel internal and external dangers."

According to Vaillant (1993), certain defenses may be adaptive. They have the following characteristics:

- they are part of a temporal perspective, being rather long term oriented;
- their mode of operation concerns the processing rather than the anesthesia (in the case of the affection);

- $\quad$ they are specific;

- they conduct feelings in a precise direction instead of block them;

- $\quad$ facilitates the acceptance by others, making the person enjoyable, appealing (Ionescu, Jacquet, \&Lhote, 2002, p. 29).

Analyzing, comparing and synthesizing different definitions in the literature, Ionescu, Jacquet, \&Lhote, (2002, p. 35), formulate their own definition which shows that "defense mechanisms are unconscious psychic processes aimed at reducing or canceling unpleasant effects of real or imaginary dangers, reshaping the internal and / or external reality and whose manifestations - behaviors, ideas have affects - can be conscious or unconscious." From the inventory of defense mechanisms made by researchers such as A. Freud, Valenstein, Laplanche and Pontalis, Bergeret, Vaillant, Plutchik and others so far, in the context of this paper we propose to detail some aspects of regression. The choice is given by the relation we can establish between the songs in the children's folklore, the theories of attachment and the permanent need of the psychic to regulate human behavior in order to find balance and harmony with oneself and with others. Regression is a defense mechanism defined by Ionescu, Jacquet, \& Lhote (2002, p. 275) as "a return - more or less organized and transient - to earlier modes of expression of thought, to objections or object relations, in front of an internal or external danger that may cause an excess of anxiety or frustration."

Regression is a defense mechanism that, according to Spitz, quoted by Ionescu, Jacquet, \& Lhote (2002, p. 67), has the prototype of sleep, as a return"to satiation when breastfeeding". Spitz believes that there is an extremely close relationship between the nature of mother-child relationships 
and the defense mechanisms that the individual will build over time to model and structure his or her character. He also argues that this relationship "drives the child's psychological development toward the use, in defense, of a particular prototype, preferred to all others."

Plutchik (1995) considers that each defense mechanism (unconscious, rigid and with limited adaptive value) corresponds to a coping method (conscious, flexible and adaptive), exemplifying that regression corresponds to seeking help. (Conte \& Plutchik, 1995, pp. 26-27)

As human aid is not always possible, the individual may resort to substitutes, alternatives such as music or other art forms. In the case of our study, we propose to build a conscious, flexible and adaptable defense behavior based on the songs from the children's folklore, which the mother sang to the individual during the first childhood. The idea is supported by the following statement attributed to Freud: "There is a return path that leads from fantasy to reality: ART."

\section{Children`s folk songs}

In this study, we explore the universe of songs in children's folklore based on the idea that "The brain is the organ we use for every imaginable cognitive task, including the perception of sound as music. Before this can happen, the incoming sound wave must be analyzed for its musically relevant properties, particularly amplitude and frequency." (Tan, Pfordresher, \&Harré, 2010, p. 51)

We therefore propose a brief analysis of the songs in the children's folklore from the perspective of the specific melodic-rhythmic structures, the content of ideas, respectively of the relation with the game and the movement, without referring to the characteristic repertoire of any ethno-folkloric zone.

Regardless of the folklore we are talking about, it is well known that the children's repertoire is struc- tured at small intervals, which they can easily sing. Very often, the vocal singing begins with the melody of the third soil, which is added to the ground to the bi-tone, and then to the ground, gradually reaching the pentatonic structure of the ground. Since ancient times, musical intervals have been assigned certain specific expressive functions. In a recent study, Costa, Bitti, \& Bonfiglioli (2000, p. 8) show that the third minor interval (e.g. Sol-mi) is associated with melancholy, sadness, and the third major (e.g. Do- mi) with stability, joy, power, purity, brilliance and tranquility. Thus, a correlation can be established between the basic core of children's folklore songs and the universe of emotions that children explore at an early age. It is interesting to note that the minor second interval (e.g. mi-fa), associated with the affect, the discouragement appears to a lesser extent in the songs in the children's folklore. The sound constructions based on consonance, on intervals with expressive functions predominantly in the area of stability, joy, balance are in full agreement with the specific rhythms of children's folklore, with the content of ideas of the songs and with the universe of emotions experienced at the age of childhood.

From a rhythmic point of view, children's songs are simple, built on succession of quarter notes and eighth notes, which gives them stability and a framework suitable for movement and play.

In an analysis of the movements suggested by the text of songs in children's folklore, Benkő \& Prezsmer (2015, p. 49) states that ,the essence of the action: continuous happening...In most cases, the game ends with a snap: a sudden change of motion, a change of role, a prompt, a question, etc."

The movements associated with children's songs are simple. These movements are meant to introduce children to adult culture, to teach children how to walk in rhythm, so that later they learn dance steps specific to adult folklore. From the point of view of the content of ideas, the songs in 
the children's folklore can be closely related to the events they accompany (different holidays Christmas, Easter, Pentecost, etc.) or they can illustrate the children's concerns in close relation with the universe they discover.

The texts of the songs in the children's folklore contain both regionalisms; archaisms that attest their authenticity, as well as words modified in meaning or form. The latter are the result of repeated transformations caused by the misunderstanding of words, the change of place names, and the desire to update the song or the spontaneous, varied interpretations of children.

\section{Children`s folk songs in music therapy}

Behaviors and activities, which occur spontaneously in childhood, can be defined by the aging of these behaviors, by adults, but also by innovative methods of music education and / or therapy. As Bowlby (1988, p. 122) states, "The presence of an attachment control system and its linkage to the working models of self and attachment figure(s) that are built in the mind during childhood are held to be central features of personality functioning throughout life." One of the expressions of attachment still less explored is the song. Articulated or not, accurate and aesthetic or not, this is the communication channel on which the mother-child relationship is built during the preverbal period of the child.

Singing creates unseen bonds between the persons, brings them into a shared space of happy exploration and expression. Even a simple breathing exercise, the prolonged sound can be transformed into a game, a musical dialogue, a journey together to what we call a safety zone.

Singing means prolonged emotional contact, interaction in which the germs of verbal communication are found, and on the other hand the nucleus of future musical and social relationships. Trevarthen\& Malloch (2000) observe not only the ef- fects of articulated singing, but also of the natural, intuitive modulation of the voice of the mother during her reaction with the child, during the swing, asleep, and crying. (Beer \& Birnbaum, 2019, p. 121)

Equally, the crying, cooing, murmuring of the child is the sound expression of his needs and emotional states. They are modulated on a scale of sounds known, recognized and interpreted by the mother who reacts accordingly. Gradually, music becomes the exponent of the individual's inner emotions and experiences, dressing them in aesthetic forms accepted and validated by others.

Music, more precisely the children's folklore songs sung at first by the mother, and later by the child, sung at adulthood even with the inner voice, can contribute to shaping adaptive defense mechanisms and behaviors. In regression, for example, the return through the songs from children's folklore during the period when the individual felt safe, was worry free, enjoyed the innocence of the age, can be an important factor in restoring the inner balance. Adaptation, psychic self-regulation through children's songs is within reach of anyone, anywhere, anytime. The effect is beneficial on the one hand because it awakens the memory of attachment relationships from early childhood, and on the other hand, because, the development of certain musical intervals with specific expressive functions (big third, small third, etc.) ordered rhythmically and in a slow tempo, induces particular emotional states.

In music therapy, songs from children's folklore can be used from different perspectives, as a solution for countless situations. In the context of the present study, we aim to bring to the fore the idea that they can be successfully used in active therapy to construct adaptive (defense) behaviors. Singing and improvising on specific topics in children's folk songs, evoking memories, emotions transmitted through children's folk songs, can generate a space of mental comfort in which the person takes 
refuge in certain situations of anxiety, depression, or over-stress. In an optimistic scenario, we consider that building defense mechanisms based on children's songs can even lead to artistic performance, can even change the perspective about life.

\section{Conclusions}

In the continuous adaptation of the individual to living conditions, he/ she frequently uses internal working models, crystallized over time. Whereas, according to Bowlby (1969), "the child's attachment relationship with their primary caregiver leads to the development of an internal working model" it is important that this relationship is a complex, resource-rich one. Singing represents a particular element of connection between mother and newborn, which can be nonverbal and non-articulated in a first stage, and gradually outlined, through a specific repertoire of songs from the children's folklore (lullabies, games, songs, etc.), in the next stages of life.

The valorization of singing from the earliest age in order to build a relationship with oneself and with others comes to complement the idea that "The internal working model is a cognitive framework comprising mental representations for understanding the world, self, and others. A person's interaction with others is guided by memories and expectations from their internal model which influence and help evaluate their contact with others." (Bretherton, \& Munholland, 1999).

Children's folk songs represent the quintessence of the human identity, they are deeply rooted in the mind and soul, and they are the first songs with which the man comes into contact when his mother sings. In music therapy, these songs represent a real spur healing.

\section{References}

Beer, L. E., \& Birnbaum, J. C. (2019). Using Music in Child and Adolescent Psychotherapy (Creative Arts and Play Therapy). New York: The Guilford Press.
Benkő, É., \& Prezsmer, B. (2015). Népi játékok. (Folk games) Sepsiszentgyörgy: Háromszék Vármegye.

Bond, M. (1992). An Empirical Study of Defensive Styles: The Defense Style Questionnaire. In G. E. Vaillant, Ego Mechanisms of Defense: A Guide for Clinicians and Researchers (pp. 127-158). Washington DC: American Psychiatric Press.

Bowlby, J. (1969). Attachment. Attachment and loss: Vol. 1. Loss. New York: Basic Books.

Bowlby, J. (1988). A Secure Base Parent-Child Attachment and Healthy Human Development. Basic Books.

Bretherton, I., \& Munholland, K. A. (1999). Internal working models revisited. In J. Cassidy, \& P. R. Shaver, Handbook of attachment: Theory, research, and clinical applications (pp. 89-111). New York: Guilford Press.

Conte, H. R., \& Plutchik, R. (1995). Ego defenses: Theory and Measurement. New York: John Wiley \& Sons, Inc.

Costa, M., Bitti, P. E., \& Bonfiglioli, L. (2000). Psychological Connotations of Harmonic Musical Intervals. Psychology of Music(28), 4-22.

Doron, R., \& Parot, F. (2006). Dicţionar de psihologie. (N. Cernățeanu, G. Dan-Spânoiu, O. Dan, S. Drăgoi, D. Florean, L.-C. Luchian, . . . D.-Ş. Săucan, Trans.) Bucureşti: Humanitas.

Guild, D. J., Toth, S. L., Handley, E. D., Rogosch, F. A., \& Cicchetti, D. (2017, May). Attachment security mediates the longitudinal association between childparent psychotherapy and peer relations for toddlers of depressed mothers. Development and Psychopathology, XXIX(2), 587-600. doi:10.1017/S0954579417000207

Ionescu, Ş., Jacquet, M.-M., \& Lhote, C. (2002). Mecanismele de apărare. Teorie şi aspecte clinice, (Defense mechanisms. Theory and clinical aspects.) (A.-P. Corescu, Trans.) Iaşi: Polirom.

Moullin, S., Waldfogel, J., \& Washbrook, E. (2018, July). Parent-child attachment as a mechanism of intergenerational (dis)advantage. Families, Relationships and Societies, VII(2), 265-284. doi:10.1332/204674317X15071998786492

Tan, S.-L., Pfordresher, P., \& Harré, R. (2010). Psychology of Music. From sound to significance. Hove and New York: Psychology Press. 